\title{
Actinic keratoses in subjects from la Mitad del Mundo, Ecuador
}

Martha Fors ${ }^{1,2^{*}}$, Paloma González ${ }^{1}$, Carmen Viada ${ }^{3}$, Kirsten Falcón ${ }^{1}$ and Santiago Palacios ${ }^{4}$

\begin{abstract}
Background: Quito, the capital of Ecuador due to its geographical location, has a high skin cancer incidence. Actinic keratoses, as premalignant lesions, are precursors of nonmelanoma skin cancer, and the prevalence of this medical condition in the country is unknown.

Methods: An observational, cross-sectional study was performed to assess the prevalence of actinic keratoses (AKs) in a rural area of Quito. Visual skin exams, dermoscopy and biopsy of suspicious lesions were performed.

Results: A total of 254 subjects older than 40 years old (71.3\% female) were enrolled. The general AK prevalence was $22.4 \%$; in women, the prevalence was $23.6 \%$, while in men, it was $19.4 \%$. The prevalence rates of basocellular and squamous cell carcinomas and Bowen disease were 1.6, 0.8 and $0.4 \%$, respectively. No statistical associations were found between AKs and the studied variables.

Conclusions: This study was the first reporting the prevalence of premalignant lesions in Ecuador. We could not demonstrate a relationship between the presence of AKs and any of the known risk factors for their development.
\end{abstract}

Keywords: Actinic keratoses (AKs), Cross-sectional study, Epidemiology, Risk factors

\section{Background}

Nonmelanoma skin cancer (NMSC) includes cutaneous squamous cell carcinomas and basal cell carcinomas. The term NMSC practically refers to keratinocyte carcinoma, basal cell carcinoma (BCC) and squamous cell carcinoma (SCC), and they account for $99 \%$ of the tumors in this group. Actinic keratoses (AKs) are considered premalignant lesions [1], and they are a common keratinocytic intraepidermal neoplasia often occurring on the chronically sun-exposed skin of Caucasian individuals $[2,3]$.

The worldwide incidence of nonmelanoma skin cancer (BCC, SCC, and Bowen's disease) is very high $[4,5]$. AKs can progress to SCC in approximately $0.1-20 \%$ of the

\footnotetext{
* Correspondence: martha.fors@udla.edu.ec

'Universidad de Las Américas (UDLA), Redondel del Ciclista, Antigua Vía a Nayón, Quito, Ecuador

¿2Universidad de Las Américas, Avenida de los Granados y Vía a Nayón, Quito, Pichincha, Ecuador

Full list of author information is available at the end of the article
}

lesions [6,7], and they are of public health importance since their presence has been associated with a significantly increased incidence of non-melanoma skin cancers.

Occupational exposure to ultraviolet (UV) radiation is high in many outdoor occupations; recent studies have suggested that persons working in such occupations are more likely to develop nonmelanoma skin cancer [8]. Geographically, Ecuador is located between $2^{\circ}$ North latitude and $5^{\circ}$ South latitude at $2850 \mathrm{~m}(9350 \mathrm{ft})$, which is a very high altitude. For every $1000 \mathrm{~m}$, UV radiation levels increase in a range from 10 to $12 \%$ [9].

According to the National Tumor Registry System of Ecuador, the incidence of nonmelanoma cancer in the period of 1986-1990 was 21 per 100,000 inhabitants, and in the period of 2006-2010, it was 33 per 100,000, indicating an increase of 57\% [10].

Excessive exposure to UV radiation is very frequent in our country. Limited data are available on the prevalence and risk factors for AKs in the Ecuadorean population,

C The Author(s). 2020 Open Access This article is licensed under a Creative Commons Attribution 4.0 International License, which permits use, sharing, adaptation, distribution and reproduction in any medium or format, as long as you give appropriate credit to the original author(s) and the source, provide a link to the Creative Commons licence, and indicate if changes were made. The images or other third party material in this article are included in the article's Creative Commons licence, unless indicated otherwise in a credit line to the material. If material is not included in the article's Creative Commons licence and your intended use is not permitted by statutory regulation or exceeds the permitted use, you will need to obtain permission directly from the copyright holder. To view a copy of this licence, visit http://creativecommons.org/licenses/by/4.0/ The Creative Commons Public Domain Dedication waiver (http://creativecommons.org/publicdomain/zero/1.0/) applies to the data made available in this article, unless otherwise stated in a credit line to the data. 
and because of the tendency of premalignant lesions to convert to malignancies, the identification of patients with AKs is very important to establish the basis of screening programs to support public health policies.

The aim of this study was to prospectively evaluate subjects living in a rural area of Quito to assess the prevalence of premalignant skin lesions (AKs) and skin cancer (NMSC) in this population. We also aimed to evaluate the relationships of AKs with age, sex, ethnicity, education level, alcohol consumption, smoking history and sun exposure habits. Skin phototype, photoaging and skin damage were also studied.

\section{Methods}

\section{Study design}

This study was a cross-sectional study to assess the prevalence of AKs.

\section{Sample size}

We included 254 Ecuadorian adults in this study. The subjects were chosen by simple random sampling from lists provided by the authorities of each town that we visited (seven towns located in la Ruta Escondida de la Mitad del Mundo).

\section{Study participants}

Full-body skin examinations were performed among participants aged 40 years old or older. The diagnosis of NMSC was made clinically and with dermoscopy as an aid for diagnosis. Skin biopsy, in addition to confirmation of diagnosis, was performed for all suspected lesions, allowing for their classification. Patients with these lesions were referred to health institutions of the Ministry of Public Health or to Centro de la Piel (CEPI) in the city of Quito.

\section{Variables}

Age, sex, ethnicity, education, alcohol consumption, smoking history and sun exposure habits were recorded. For the analysis, age was dichotomized into ages 40-65 and 65 and older. Educational level was classified into six categories: none, primary, secondary, high school, technical and university qualifications. Smoking status was classified into three categories: nonsmoker, exsmoker and smoker. Other variables were also grouped. Skin phototype was measured with the Fitzpatrick Skin Phototype Classification (FSPC, type I, II, III, IV, V or VI). Severity grading of photoaging was performed using the Glogau scale (type I "no wrinkles" to type IV "only wrinkles"). Skin damage was assessed using the SCIN EXA scale.

\section{Statistical analysis}

Quantitative variables are expressed as the means and standard deviation. Absolute numbers and percentages were used for qualitative variables. The prevalence of actinic keratoses was calculated using as the denominator the total number of subjects in the sample and as the numerator those subjects with AKs.

The Chi square-test or Fisher's exact test was used for intergroup comparisons as appropriate. Multivariate analysis was used for a logistic regression model. Variables were entered into the logistic model if the $p$ values were less than 0.25 in the univariate analysis. Statistical tests were two sided, with an alpha of 0.05. SPSS 24.0 for Windows was used for data processing.

\section{Results}

The study included 254 subjects living in La Ruta Escondida de la Mitad del Mundo. The prevalence rates of basocellular and squamous cell carcinomas and Bowen disease were 1.6, 0.8 and $0.4 \%$, respectively. NMSC was diagnosed by biopsy. Actinic keratoses were diagnosed in $22.4 \%$ (95\% CI: $17-28$ ) of the included subjects (Fig. 1).

Women comprised the majority (71.3\%) of the sample. The prevalence according to sex was $23.6 \%$ for women (43 of 182), while the frequency of this medical condition in men was $19.4 \%$ (14 of 72).

The participants' mean age was $60.8 \pm 13.8$ years old, while the median age was 60 years old.

Most of the participants were between 40 and 65 years old and had less than a complete primary education. Almost $90 \%$ of the included participants were Mestizos and had no drinking history. Actinic keratoses were more frequent in subjects older than 65 years old, as well as in Mestizos. No relationship was established between the studied variables and the presence of actinic keratoses (Table 1).

Most of the subjects included in this study had no sun protection. We found that 35 subjects of the 57 with AKs (61.4\%) did not use protection against the sun. Most subjects with AKs worked outdoors, and those with more than $6 \mathrm{~h}$ outdoors were more frequent. More than $70 \%$ of the subjects with actinic keratoses never used makeup. The relationships between AKs and all sun exposure habits were not statistically significant (Table 2).

More than $60 \%$ of subjects with AKs had mild and moderate elastosis. Cutis rhomboidal was also more frequent in subjects with AKs. There were nonsignificant differences between the groups (Table 3).

Most of the subjects were classified as type II or III on the Glogau scale (moderate or advanced photoaging). In patients with AKs, more than $65 \%$ had Fitzpatrick skin type IV, and $24.6 \%$ of patients had skin type III. The 


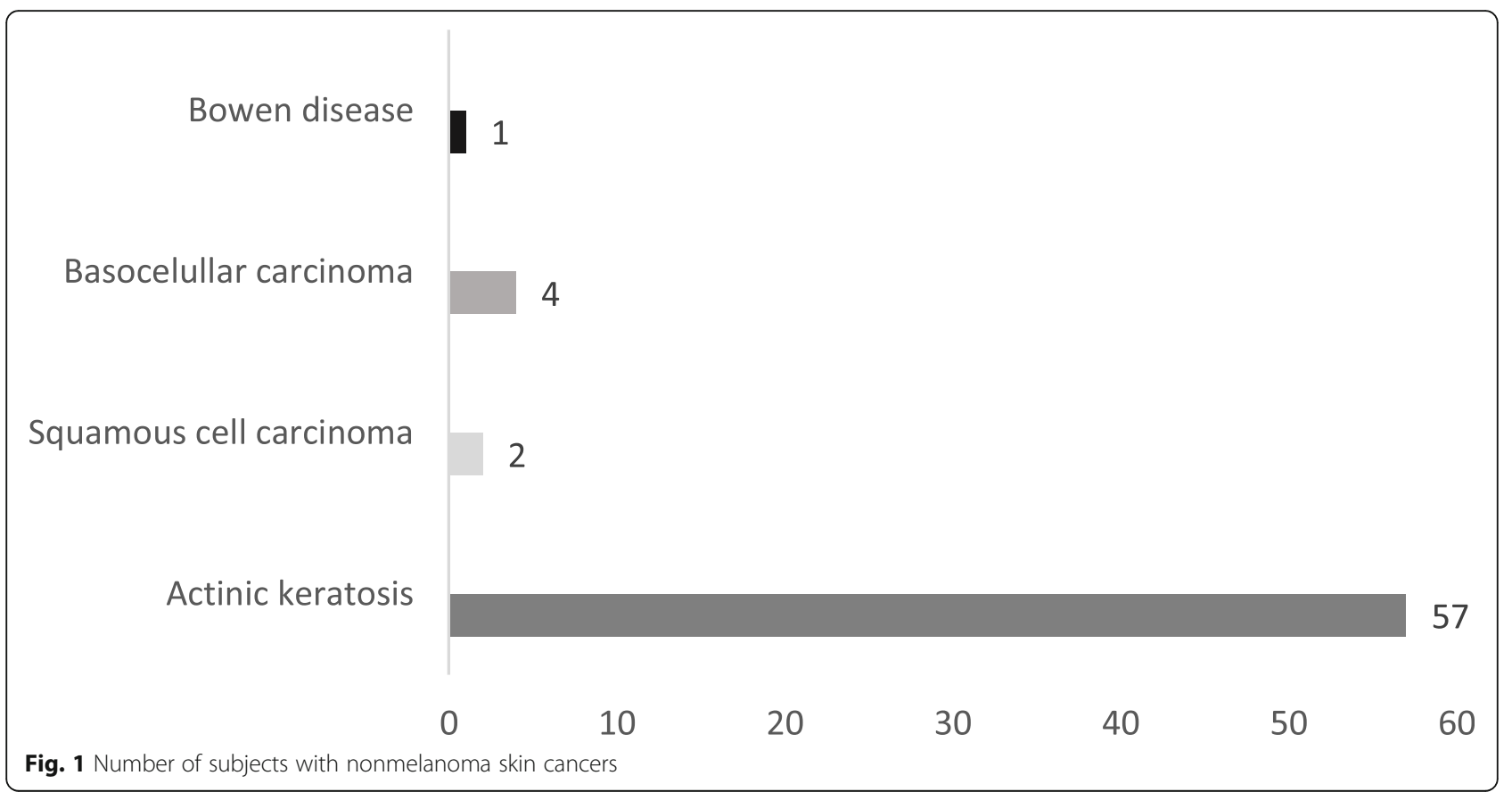

distribution of patients with AKs among all of the variables included was not statistically significant (Table 4).

Table 5 shows the unadjusted and adjusted associations between the presence of AKs and possible risk factors. None of these factors represented a risk for the development of AKs in this population.

\section{Discussion}

To our knowledge, there have been no previous studies of AK prevalence in our country. This medical condition is considered a precancerous epidermal lesion caused by long-term exposure to UV radiation, which can progress to squamous cell carcinoma. Bowen's disease is also a representative cutaneous premalignant lesion.

Many epidemiological studies have examined the prevalence of malignant cutaneous tumors, but epidemiological studies of premalignant lesions have not been very frequent. Previous studies among Caucasian populations have provided substantial epidemiological data, but little has been published about trends for skin cancers in our population, which has a darker skin color.

This study included age, sex, ethnic group, alcohol consumption, smoking history and sun behavior/exposure habits. The Glogau scale for photoaging, Fitzpatrick scale and SCINEXA scale were used to evaluate skin conditions to assess for possible risk factors for the development of actinic keratoses. AKs are a chronic disease arising on skin with actinic damage, requiring treatments, as well as regular follow-up; therefore, an opportune diagnosis and the control of possible causes are necessary.
AKs were the most frequent premalignant lesions. In our study, $24.2 \%$ of all of the subjects included in the study presented this kind of lesion. Bowen's disease appeared in $1.6 \%$ of the included subjects. AK prevalence was higher in patients $>65$ years of age and in patients with Fitzpatrick skin types II and III. These results are similar to those obtained by Akdeniz et al. and Hahnel et al. [11, 12]. Similar figures of AK prevalence were found in the EPIQA study by Ferrandiz et al. [13].

Eder et al. [7] showed an overall AK prevalence of $31.0 \%$, which was higher in men than in women. Similar results were found by Dziunycz et al. [14]; nevertheless, the current study reported that AKs were more frequent in women, but we also had more women than men in our sample.

Many studies $[15,16]$ have demonstrated a high prevalence of AKs among outdoor workers, and in the current study, the number of subjects with this type of lesion who work outdoors was also high. The study region is mainly devoted to growing flowers and other agricultural tasks, and most of the participants spend long periods of time outdoors, usually without adequate protection from the sun. Incomes are also very low, and buying sunscreen is not an option for this population. Nevertheless, they use other ways to protect themselves from the sun, such as wearing hats and long sleeves.

The pattern of continuous sun exposure is protective in people who have good adaptability, and it is our belief that the subjects of this study are well adapted. 
Table 1 Characterization of participants according the presence of actinic keratoses

\begin{tabular}{lllll}
\hline Demographics & \multicolumn{2}{l}{ Actinic Keratoses } & P value \\
\cline { 2 - 3 } & No & & Yes \\
& $n=197(77.6 \%)$ & & $n=57(22.4 \%)$ \\
\cline { 2 - 2 } & No. $\quad \%$ & & No. $\%$
\end{tabular}

\section{Sex}

$\begin{array}{lllll}\text { Male } & 58 & 80.6 & 14 & 19.4 \\ \text { Female } & 139 & 76.4 & 43 & 23.6\end{array}$

Age group

$\begin{array}{lllll}40-65 & 127 & 80.4 & 31 & 19.6 \\ >65 & 70 & 72.9 & 26 & 27.1\end{array}$

Education

$\begin{array}{lllll}\text { None } & 19 & 65.5 & 10 & 34.5 \\ \text { Primary } & 111 & 75.5 & 36 & 24.5 \\ \text { Secondary } & 38 & 86.4 & 6 & 13.6 \\ \text { High school } & 5 & 100.0 & 0 & 0.0 \\ \text { Technical } & 4 & 100.0 & 0 & 0.0 \\ \text { University } & 20 & 80.0 & 5 & 20.0\end{array}$

Ethnic

$\begin{array}{lllll}\text { Mestiza } & 173 & 77.4 & 50 & 22.6 \\ \text { Other } & 24 & 77.6 & 7 & 22.4\end{array}$

Alcohol consumption

\begin{tabular}{llllll} 
Never & 116 & 78.4 & 32 & 21.6 & 0.31 \\
Hardly ever & 75 & 77.3 & 22 & 22.7 & \\
Often & 6 & 75 & 2 & 25.0 & \\
Always & 0 & 0 & 1 & 100.0 & \\
Smoking history & & & & & \\
Nonsmoker & 19 & 79.2 & 5 & 20.8 & 0.50 \\
Ex-smoker & 158 & 76.3 & 49 & 23.7 & \\
Smoker & 20 & $87 \%$ & 3 & 13.0 & \\
\hline
\end{tabular}

Although it is known that there are several risk factors for AK development, such as sex, age, UV exposure and skin type, this study could not support this theory since we did not find any statistical relationships among possible risk factors and the presence of AKs or other premalignant lesions.

The role of UV exposure in the development of AKs has been discussed by some authors [17-19], and only in a few studies has a negative or no relationship between sun exposure and the sun-related risks associated with the occurrence of AKs and/or skin cancer been reported [20].

Multiple genetic and environmental factors might interfere with the risk of developing AKs [21]; in particular, in this study, we could not identify these factors. The relative risk of AKs was 14.1 times higher in fair skinned patients than in those with dark skin [22].
Table 2 Sun exposure and protection habits according to the presence of actinic keratoses

\begin{tabular}{llll}
\hline Habits & \multicolumn{2}{l}{ Actinic Keratoses } & P value \\
\cline { 2 - 3 } & No & Yes & \\
& $n=197(77.6 \%)$ & & $n=57(22.4 \%)$ \\
\cline { 2 - 2 } & No. $\%$ & No. $\%$ \\
\hline
\end{tabular}

\begin{tabular}{cccccc}
\hline \multicolumn{2}{l}{ Sun protection behavior } & & & & \\
Yes & 69 & 75.8 & 22 & 24.2 & 0.62 \\
No & 128 & 78.5 & 35 & 21.5 &
\end{tabular}

Sun exposure per day

$\begin{array}{lllll}\text { Less than } 3 \mathrm{~h} & 75 & 79.8 & 19 & 20.2 \\ \text { From } 3 \text { to } 6 \mathrm{~h} & 39 & 70.9 & 16 & 29.1 \\ \text { More than } 6 \mathrm{~h} & 83 & 79.0 & 22 & 21.0\end{array}$

Frequency of sun protection

$\begin{array}{lllll}\text { Never } & 126 & 78.3 & 35 & 21.7 \\ \text { Hardly ever } & 31 & 73.8 & 11 & 26.2 \\ \text { Often } & 15 & 71.4 & 6 & 28.6 \\ \text { Always } & 25 & 83.3 & 5 & 16.7\end{array}$

Makeup use

$\begin{array}{lllll}\text { Never } & 160 & 79.2 & 42 & 20.8 \\ \text { Hardly ever } & 25 & 65.8 & 13 & 34.2 \\ \text { Often } & 5 & 71.4 & 2 & 28.6 \\ \text { Always } & 7 & 100.0 & 0 & 0.0\end{array}$

Working outdoors

\begin{tabular}{llllll} 
Yes & 153 & 77.7 & 44 & 22.3 & 0.90 \\
No & 44 & 77.2 & 13 & 22.9 & \\
\hline
\end{tabular}

Table 3 Prevalence of UV light-related signs of skin aging according actinic keratoses

\begin{tabular}{|c|c|c|c|c|c|}
\hline & \multicolumn{4}{|c|}{ Actinic Keratoses } & \multirow[t]{3}{*}{$P$ value } \\
\hline & \multicolumn{2}{|c|}{$\begin{array}{l}\text { No } \\
n=197(77.6 \%)\end{array}$} & \multicolumn{2}{|c|}{$\begin{array}{l}\text { Yes } \\
n=57(22.4 \%)\end{array}$} & \\
\hline & No. & $\%$ & No. & $\%$ & \\
\hline \multicolumn{6}{|c|}{ Severity of elastosis } \\
\hline None & 58 & 29.4 & 18 & 31.6 & 0.76 \\
\hline Mild & 92 & 46.7 & 23 & 40.4 & \\
\hline Moderate & 41 & 20.8 & 13 & 22.8 & \\
\hline Severe & 6 & 3.0 & 3 & 5.3 & \\
\hline \multicolumn{6}{|c|}{ Cutis rhomboidal } \\
\hline Yes & 34 & 17.3 & 12 & 21.1 & 0.51 \\
\hline No & 163 & 82.7 & 45 & 78.9 & \\
\hline \multicolumn{6}{|c|}{ Favre-Racouchot } \\
\hline Yes & 1 & 0.5 & 2 & 3.5 & 0.06 \\
\hline No & 196 & 99.5 & 55 & 96.5 & \\
\hline
\end{tabular}


Table 4 Prevalence of photoaging, skin phototype and skin damage according actinic keratoses

\begin{tabular}{|c|c|c|c|c|c|}
\hline \multirow[t]{3}{*}{ Scales } & \multicolumn{4}{|c|}{ Actinic Keratoses } & \multirow[t]{3}{*}{$P$ value } \\
\hline & \multicolumn{2}{|c|}{$\begin{array}{l}\text { No } \\
n=197(77.6 \%)\end{array}$} & \multicolumn{2}{|c|}{$\begin{array}{l}\text { Yes } \\
n=57(22.4 \%)\end{array}$} & \\
\hline & No. & $\%$ & No. & $\%$ & \\
\hline \multicolumn{6}{|c|}{ Glogau } \\
\hline । & 16 & 8.1 & 3 & 5.3 & 0.29 \\
\hline$\|$ & 66 & 33.5 & 22 & 38.6 & \\
\hline III & 86 & 43.7 & 19 & 33.3 & \\
\hline IV & 29 & 14.7 & 13 & 22.8 & \\
\hline \multicolumn{6}{|c|}{ Fitzpatrick } \\
\hline । & 0 & 0 & 0 & 0 & 0.62 \\
\hline$\|$ & 5 & 2.5 & 1 & 1.8 & \\
\hline III & 69 & 5.0 & 15 & 24.6 & \\
\hline IV & 114 & 57.9 & 38 & 66.7 & \\
\hline V & 9 & 4.6 & 3 & 5.3 & \\
\hline $\mathrm{VI}$ & 0 & 0 & 0 & 0 & \\
\hline \multicolumn{6}{|c|}{ SCINEXA (skin damage) } \\
\hline Yes & 154 & 78.2 & 45 & 78.9 & 0.90 \\
\hline No & 43 & 21.8 & 12 & 21.1 & \\
\hline
\end{tabular}

Table 5 Unadjusted and adjusted associations between AKs and some possible risk factors

\begin{tabular}{|c|c|c|}
\hline \multirow[t]{2}{*}{ Characteristics } & Nonadjusted & Adjusted \\
\hline & OR $(95 \% \mathrm{Cl})$ & OR $(95 \% \mathrm{Cl})$ \\
\hline \multicolumn{3}{|l|}{ Sex } \\
\hline Male & Reference & \\
\hline Female & $1.28(0.65-2.52)$ & $1.50(0.68-3.30)$ \\
\hline \multicolumn{3}{|l|}{ Age } \\
\hline $40-65$ & Reference & \\
\hline$>65$ & $1.57(0.83-2.76)$ & $1.71(0.76-3.84)$ \\
\hline \multicolumn{3}{|l|}{ Ethnicity } \\
\hline Other & Reference & \\
\hline Mestiza & $0.99(0.40-2.43)$ & $0.84(0.31-2.26)$ \\
\hline \multicolumn{3}{|l|}{ Fitzpatrick } \\
\hline$\|$ & Reference & \\
\hline III & $1.02(0.11-9.50)$ & $1.20(0.12-0.57)$ \\
\hline IV & $1.73(0.19-15.33)$ & $2.15(0.23-20.12)$ \\
\hline V & $1.11(0.07-15.53)$ & $1.17(0.08-17.07)$ \\
\hline \multicolumn{3}{|c|}{ Working outdoors } \\
\hline No & Reference & \\
\hline Yes & $1.02(0.50-2.07)$ & $1.22(0.52-2.85)$ \\
\hline \multicolumn{3}{|l|}{ Glogau } \\
\hline । & Reference & \\
\hline$\|$ & $1.77(0.47-6.68)$ & $1.63(0.42-6.28)$ \\
\hline III & $1.17(0.31-4.45)$ & $0.93(0.23-3.75)$ \\
\hline IV & $2.39(0.59-9.65)$ & $1.44(0.29-7.12)$ \\
\hline
\end{tabular}

According to a study of Japanese subjects, the intensity of solar radiation is directly related to the prevalence of AKs; three times more lesions were observed in patients living in lower latitudes who were exposed to double the incidence of ultraviolet radiation B (UVRB) [23]. The subjects from this study live in such areas, so further studies should be performed to compare the prevalence of AKs with other subjects living in different regions of Ecuador.

\section{Conclusions}

In our consideration, our results provide a reliable estimate of the prevalence of AKs in this region. This study was the first reporting premalignant lesion prevalence in Ecuador since AKs are the most common diagnosis and finding not related to any of the known risk factors for their development.

\section{Limitations}

It is well known that UV exposure plays an important role in the development of AKs and NMSC, but the intensity and duration of UV exposure were not measured in the current study, constituting one of the most important limitations of the study.

Similarly, we have not evaluated the intensity and duration of the smoking history, which might be another important modifiable risk factor. Another limitation of the study includes the lack of information on past AKs and timing of first appearance before skin examination performed during this study. Most of the data were based on patient self-reports. Most of the subjects who were recruited were women.

\section{Abbreviations}

AKs: Actinic keratoses; CEISH-UDLA: Ethics committee from the university UDLA; SCINEXA: SCore for INtrinsic and EXtrinsic skin Aging; UDLA: Universidad de Las Américas; UVRB: Ultraviolet radiation B; UV: Ultraviolet

\section{Acknowledgments}

The authors thank all of the subjects who participated in the study and Universidad de Las Américas for its financial support in performing this investigation. Additionally, we thank Centro de la Piel for its valuable contributions.

\section{Authors' contributions}

$\mathrm{MF}$ and SP worked on the design of the research. MF and CV were responsible for the data analysis, interpretation, drafting, and revision of the work. MF, SP, PG and KF collected the data. All of the authors participated in the interpretation and revision process of the manuscript. All of the authors gave their final approval of the version to be published.

\section{Funding}

This research was funded by Universidad de Las Américas. The university financed equipment for the diagnosis of skin lesions, as well as travel expenses to the study region. The code of the project funded was MED.MF.17.08

Availability of data and materials

The datasets used and/or analyzed during the current study are available from the corresponding author upon reasonable request. 


\section{Ethics approval and consent to participate}

Ethics approval was obtained from the ethics committee of the Universidad de Las Américas. All of the patients were informed of the benefits and risks related to the study and provided their written informed consent for the study and for the publication of results. We followed the STROBE guidelines for the reporting of this study.

\section{Consent for publication}

Not applicable.

\section{Competing interests}

The authors declare that this research was conducted in the absence of any commercial or financial relationships that could be construed as potential conflicts of interest.

\section{Author details}

'Universidad de Las Américas (UDLA), Redondel del Ciclista, Antigua Vía a Nayón, Quito, Ecuador. ${ }^{2}$ Universidad de Las Américas, Avenida de los Granados y Vía a Nayón, Quito, Pichincha, Ecuador. ${ }^{3}$ Centro de Inmunología Molecular, Habana, Cuba. ${ }^{4}$ Pontificia Universidad del Ecuador (PUCE), Quito, Ecuador

Received: 21 October 2019 Accepted: 14 October 2020

Published online: 27 October 2020

\section{References}

1. Katalinic A, Kunze U, Schäfer T. Epidemiology of cutaneous melanoma and non-melanoma skin cancer in Schleswig-Holstein, Germany: incidence, clinical subtypes, tumour stages and localization (epidemiology of skin cancer). Br J Dermatol. 2003;149:1200-6.

2. LeBoit P, Burg G, Weedon D, Sarasain A. World Health Organization classification of tumours. In: Pathology and genetics of skin tumours. Lyon: IARC Press; 2006

3. Fernández-Figueras MT, Carrato C, Sáenz X, Puig L, Musulen E, Ferrándiz C, Ariza A. Actinic keratosis with atypical basal cells (AK I) is the most common lesion associated with invasive squamous cell carcinoma of the skin. J Eur Acad Dermatol Venereol. 2015;29(5):991-7. https://doi.org/10.1111/jdv.12848 Epub 2014 Nov 26

4. Leiter U, Eigentler T, Garbe C. Epidemiology of skin cancer. Adv Exp Med Biol. 2014;810:120-40.

5. Schulze HJ, Cribier B, Requena L, Reifenberger J, Ferrándiz C, Garcia Diez A, et al. Imiquimod $5 \%$ cream for the treatment of superficial basal cell carcinoma: results from a randomized vehicle-controlled phase III study in Europe. Br J Dermatol. 2005;152:939-47.

6. Quaedvlieg P, Tirsi E, Thissen M, Krekels G. Actinic keratosis: how to differentiate the good from the bad ones? Eur J Dermatol. 2006;16(4):335-9.

7. Eder J, Prillinger K, Korn A, Geroldinger A, Trautinger F. Prevalence of actinic keratosis among dermatology outpatients in Austria. Br J Dermatol. 2014; 171(6):1415-21. https://doi.org/10.1111/bjd.13132.

8. Fartasch M, Diepgen TL, Schmitt J, Drexler $H$. The relationship between occupational sun exposure and non-melanoma skin cancer: clinical basics, epidemiology, occupational disease evaluation, and prevention. Dtsch Arztebl Int. 2012;109(43):715-20. https://doi.org/10.3238/arztebl.2012.0715.

9. UV INDEX SOLAR - World Health Organization. (n.d.). Retrieved October 19, 2020, from https://www.who.int/uv/publications/en/UVIGuide.pdf.

10. Registro Nacional de Tumores. (n.d.). Epidemiología del Cáncer en Quito 2006-2010. Retrieved October 19, 2020, from https://issuu.com/solcaquito/ docs/epidemiologia_de_cancer_en_quito_20.

11. Akdeniz M, Hahnel E, Ulrich C, Blume-Peytavi U, Kottner J. Prevalence and associated factors of skin cancer in aged nursing home residents: a multicenter prevalence study. PLoS One. 2019;14(4):e0215379. https://doi.org/10.1371/journal.pone.0215379.

12. Hahnel E, Blume-Peytavi U, Trojahn C, Dobos G, Jahnke I, Kanti V, et al. Prevalence and associated factors of skin diseases in aged nursing home residents: a multicentre prevalence study. BMJ Open. 2017;7(9):e018283.

13. Ferrándiz-Pulido C, Lera-Imbuluzqueta M, Ferrándiz C, Plazas-Fernandez M. Prevalence of actinic keratosis in different regions of Spain: the EPIQA study. Actas Dermosifiliogr. 2018;109(1):83-6. https://doi.org/10.1016/j.ad.2017.05. 014.
14. Dziunycz PJ, Schuller E, Hofbauer GFL. Prevalence of actinic keratosis in patients attending general practitioners in Switzerland. Dermatology. 2018 : 1-6. https://doi.org/10.1159/000491820.

15. Schaefer I, Augustin M, Spehr C, Reusch M, Kornek T. Prevalence and risk factors of actinic keratoses in Germany - analysis of multisourcedata. J Eur Acad Dermatol Venereol. 2014;28:309-13.

16. Flohil SC, Dowlatshahi EA, Hofman A, de Vries E, Nijsten T. Prevalence of actinic keratosis and its risk factors in the general population: the Rotterdam study. J Invest Dermatol. 2013;133:1971-8.

17. Roewert-Huber J, Stockfleth E, Kerl H. Pathology and pathobiology of actinic (solar) keratosis - an update. Br J Dermatol. 2007;157(suppl 2):18-20.

18. Calzavara-Pinton $P$, Ortel $B$, Venturini M. Non-melanoma skin cancer, sun exposure and sun protection. G Ital Dermatol Venereol. 2015;150:369-78,

19. Surdu S, Fitzgerald E, Bloom M, Boscoe F, Carpenter D, Haase R, Gurzau E, Rudnai P, Koppova K, Févotte J, Leonardi G, Vahter M, Goessler W, Kumar R, Fletcher T. Occupational exposure to ultraviolet radiation and risk of nonmelanoma skin cancer in a multinational European study. PLoS One. 2013; 8(4):e62359. https://doi.org/10.1371/journal.pone.0062359 Published online 2013 Apr 24.

20. Akarsu S, Ozbagcivan O, Ilknur T, Semiz F, Fetil E. Sun-related risk factors, perceived seriousness of disease and accompanying non-melanoma skin cancer in patients with actinic keratoses. Dermatol Sin. 2017;36(2):79-84.

21. Rossi R, Mori M, Lotti T. Actinic keratosis. Int J Dermatol. 2007;46:895-904.

22. Lebwohl M. Actinic keratosis: epidemiology and progression to squamous cell carcinoma. Br J Dermatol. 2003;149(Suppl 66):31-3.

23. Araki K, Nagano T, Ueda M, Washio F, Watanabe $\mathrm{S}$, Yamaguchi $\mathrm{N}$, et al. Incidenceof skin cancers and precancerous lesions in Japanese--risk factors and prevention. J Epidemiol. 1999;9:S14-21.

\section{Publisher's Note}

Springer Nature remains neutral with regard to jurisdictional claims in published maps and institutional affiliations.

\section{Ready to submit your research? Choose BMC and benefit from:}

- fast, convenient online submission

- thorough peer review by experienced researchers in your field

- rapid publication on acceptance

- support for research data, including large and complex data types

- gold Open Access which fosters wider collaboration and increased citations

- maximum visibility for your research: over $100 \mathrm{M}$ website views per year

At BMC, research is always in progress.

Learn more biomedcentral.com/submissions 